Diabetologia 9, 477-482 (1973)

(c) by Springer-Verlag 1973

\title{
Effect of Carbohydrates upon Fluorescence of Reduced Pyridine Nucleotides from Perifused Isolated Pancreatic Islets
}

\author{
U. Panten, J. Christians, E. v. Kriegstein, W. Poser and A. Hasselblatt \\ Pharmakologisches Institut der Universität Göttingen, Göttingen, Germany (FRG) \\ Received: October 18, 1972, and in revised form: July 13, 1973
}

\begin{abstract}
Summary. In perifused pancreatic islets, the fluorescence of reduced pyridine nucleotides $(\mathrm{NAD}(\mathrm{P}) \mathrm{H})$ was measured continuously. Elevation of glucose concentration in the medium from $0-5 \mathrm{mM}$ to $20 \mathrm{mM}$ led to an increase in $\mathrm{NAD}(\mathrm{P}) \mathrm{H}$-fluorescence beginning $10-20 \mathrm{sec}$ after change of medium. Perifusion with calcium-free media had no influence on this effect. It was, however, partially or completely blocked by 2 -deoxy D-glucose, D-glucosamine, or D-mannoheptulose. D-mannose, but not D-fructose and L-lactate, enhanced $\mathrm{NAD}(\mathrm{P}) \mathrm{H}$ -
\end{abstract}

fluorescence from pancreatic islets. Pyruvate caused but a small fluorescence increase. From these observations it is concluded that D-glucose leads to the increase of NAD(P)H-fluorescence by mediation of the phosphoglyceraldehyde dehydrogenase reaction.

Key words: Pancreatic islets, rats, obese-hyperglycemic mice, perifusion, fluorescence, reduced pyridine nucleotides, D-glucose, D-mannoheptulose, L-lactate.
A constant stimulation of the perfused rat pancreas with glucose triggered a multiphasic insulin release [1]. In order to explain this secretion pattern, the authors suggested a two-compartment model of insulin secretion. Other explanations, however, are possible. Modulation of the secretory response of the $\beta$-cell by metabolic events has been discussed $[1,2,3]$ and is supported by recent experimental results $[3,4]$. Thus there is a need for detailed information on the time course of the metabolic conditions of the $\beta$-cell during different functional states. Continuous recording of the fluorescence of reduced pyridine nucleotides $(\mathrm{NAD}(\mathrm{P})$ H.) has been used to monitor the redox state of perfused organs $[5,6]$ or perifused tissues $[7,8]$. Since pyridine nucleotides take part in all degradation pathways of glucose, the above-mentioned technique seemed to be especially suited to trace the effects of carbohydrates on $\beta$-cell metabolism. Preliminary results of some of the following observations have been reported elsewhere [9].

\section{Materials and Methods}

\section{Chemicals}

The following substances, which contained no fluorescent impurities, were added: D-mannoheptulose from Schering, Berlin; D-glucosamine hydrochloride and mannitol from Fluka, Buchs; tolbutamide and glucagon from Farbwerke Hoechst, Hoechst; 2-deoxyD-glucose, sodium L-lactate, sodium succinate, urea and pentobarbital from Serva, Heidelberg. All other substances were obtained from Merck, Darmstadt. The substances were of highest purity available from the companies.

\section{Perifusion of Pancreatic Islets}

6-8 month old obese-hyperglycemic mice of both sexes were starved for $20-28 \mathrm{~h}$ and killed by decapitation. The mice are bred in our institute since 1966 and originate from a Bar Harbor strain. Pancreatic islets or pieces of exocrine pancreas of similar size were dissected within 30 min at $+2^{\circ}$ in Krebs-Ringer phosphate buffer containing $3.3 \mathrm{mM}$ glucose [10]. Some experiments were performed on islets or exocrine pancreas from fed male albino mice (strain NMRI) or from starved $(20-28 \mathrm{~h})$ male albino rats $(180-200 \mathrm{~g}$, Sprague-Dawley), dissecting the tissues as described above.

Perifusion at $85 \mu \mathrm{l} / \mathrm{min}$ and $+36^{\circ}$ was performed as described [11]. The medium consisted of KrebsRinger bicarbonate buffer. When insulin secretion was measured, the medium was supplemented with $2 \mathrm{mg} / \mathrm{ml}$ bovine serum albumin (Behringwerke, Marburg) and collected in 4 min fractions. When media contained sodium salts of substrates, equimolar amounts of sodium chloride were omitted. Control experiments, however, showed that the fluorescence traces from islets remained unchanged when switching to a medium containing additional sodium chloride $(20 \mathrm{mM})$. Glueagon was dissolved in the gassed medium immediately before starting perifusion. It was not possible to use albumin in fluorometric studies since it enhanced the background fluorescence. A roller pump sucked the selected medium through a distribution valve without dead space $(0.5 \mathrm{~mm}$ bore diameter). The pump and the perifusion chamber were connected by a polythene tube $(0.2 \mathrm{~mm}$ inner diameter). Thus pulsations of the flow were damped. The distance the medium travelled from the valve to the top of the chamber was measured by switching to a medium supplemented with methylumbelliferone and monitoring the fluorescence. Thus the beginning of medium change at the islet could be 
set $( \pm 3 \mathrm{sec}$ ). The kinetics of medium change in the longitudinal axis of the chamber took place with a time constant of about 70 sec. Each experiment was repeated 5 times using different islets $(0.3-0.5 \mathrm{~mm}$, longest diameter) and a glucose stimulus as a reference value. The described typical effects on insulin secretion and $\mathrm{NAD}(\mathrm{P}) \mathrm{H}$-fluorescence were always seen.

\section{Analytical}

$\mathrm{NAD}(\mathrm{P}) \mathrm{H}$-fluorescence was measured as described [11]. A water-cooled ST41 mercury are (Original Hanau) was used. The photomultiplier output was fed to a recorder (PM 8100, Philips). The time constant of the set-up was 3 sec. Immunologically reactive insulin was measured as described [12] using ox insulin as standard. Calcium content of the media was controlled by atomic absorption. By omission of calcium, levels lower than $0.1 \mathrm{mEq} / 1$ were obtained.

\section{Results}

When switching from a medium with low glucose concentration $(3.5 \mathrm{mM})$ to a medium with high glucose concentration $(20 \mathrm{mM})$ the isolated mouse islet responded with an increase of the $\mathrm{NAD}(\mathrm{P}) \mathrm{H}$-fluorescence starting $10-20$ sec after arrival of the medium rich in
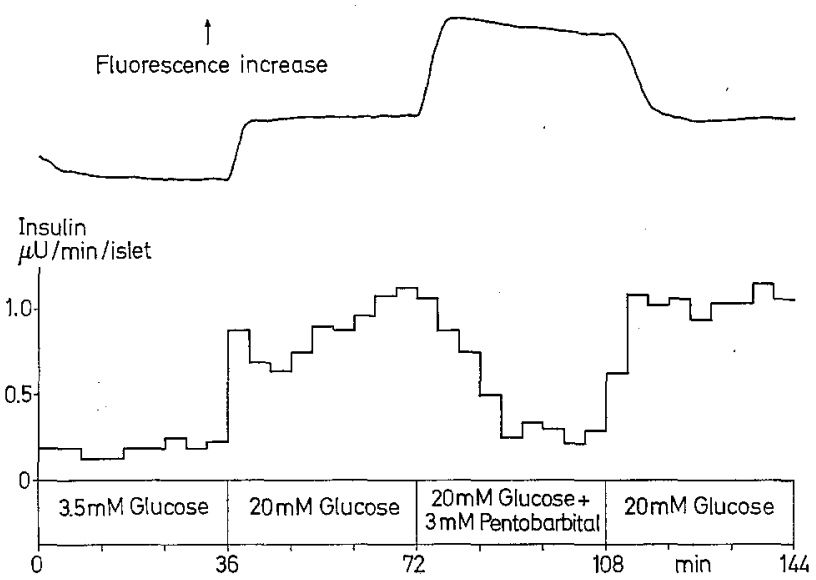

Fig. 1. Effects of D-glucose and pentobarbital on NAD(P)H-fluorescence trace (upper curve) of a perifused single albino mouse islet $(0.3 \mathrm{~mm}$ longest diameter). In a parallel experiment the amount of insulin released was immunoassayed (longest diameter of islet $0.3 \mathrm{~mm}$ )

glucose at the islet and reaching its maximum $3 \mathrm{~min}$ later (Fig. 1). This reduction of the pyridine nucleotides was enhanced by pentobarbital. Pentobarbital blocks the respiratory chain between two flavoproteins [13]. Thus it induces an accumulation of reduced pyridine nucleotides and a lack of high energy intermediates. The latter action of the drug explains the inhibition of insulin release. When performing a similar transition to media with high glucose concentrations, the beginning of the fluorescence increase of the bigger islets from obese-hyperglycemic mice could be detected 10-15 sec after medium change started (Fig. 2). The new steady state was reached within about $10 \mathrm{~min}$. This transition time depended on the size of the islets $(0.3-0.5 \mathrm{~mm}$ longest diameter) and lasted 6-12 min. The latter differences probably reflect diffusion kinetics of glucose into the islets.

Mannitol, urea or succinate did not change the fluorescence trace (Fig. 3). Thus artifacts as caused by shrinking or swelling of the cells or by increased oxygen consumption are ruled out.

Fructose does not stimulate insulin secretion and mannose releases less insulin than glucose $[14,15]$. A similar relationship between the three sugars exists concerning the fluorescence increase (Fig. 4). In these experiments, the reduction of pyridine nucleotides was completed rather rapidly (within $5 \mathrm{~min}$ ) when compared

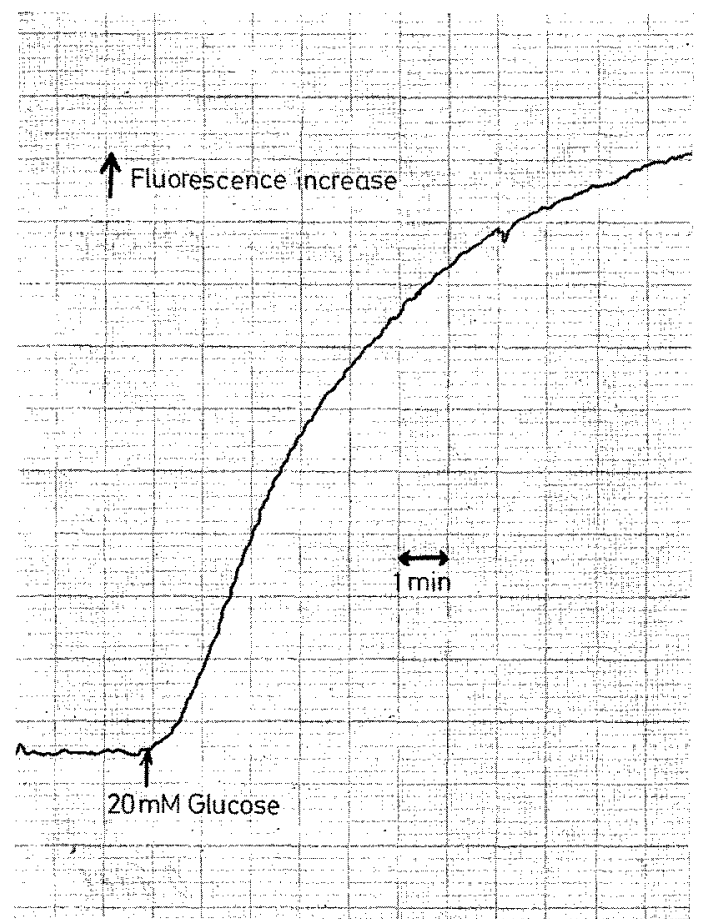

Fig. 2. Effect of $20 \mathrm{mM}$ D-glucose on $\mathrm{NAD}(\mathrm{P}) \mathrm{H}$-fluorescence trace of a single islet $(0.45 \mathrm{~mm}$ longest diameter), which was microdissected from an obese-hyperglycemic mouse. The islet was perifused previously with $5 \mathrm{mM}$ glucose. The arrow marks the moment when the medium containing $20 \mathrm{mM} \mathrm{D}$-glucose arrived at the islet

with the kinetics obtained by switching from $5 \mathrm{mM}$ glucose to $20 \mathrm{mM}$ glucose (compare also Fig. 3. with 5 and 6). These differences may be explained by the reduction of pyridine nucleotides caused by $5 \mathrm{mM}$ glucose.

In contrast to 2-deoxyglucose, mannoheptulose and glucosamine inhibited glucose induced insulin release [15]. $20 \mathrm{mM}$ mannoheptulose lowered the NAD(P)Hfluorescence emitted from islets perifused with $20 \mathrm{mM}$ glucose (Fig. 5) or $20 \mathrm{mM}$ mannose (not shown). The 
fluorescence decrease started $30-60$ sec after arrival of mannoheptulose at the islets. When switching again to a mannoheptulose-free medium, a very slow increase of $\mathrm{NAD}(\mathrm{P}) \mathrm{H}$-fluorescence began about $13 \mathrm{~min}$ after medium change, reaching a plateau about $60 \mathrm{~min}$ after medium change.

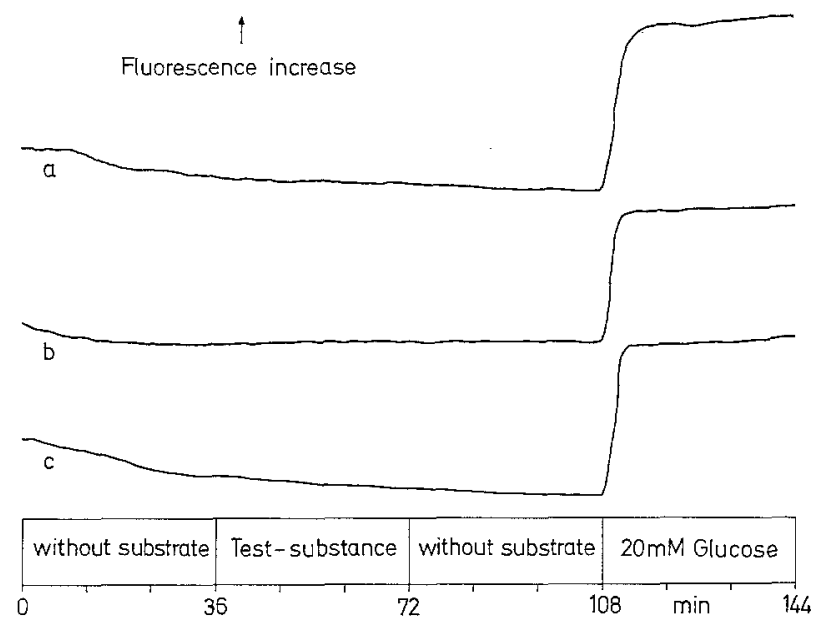

Fig. 3. NAD(P)H-fluorescence traces of perifused single islets, which were microdissected from obese-hyperglycemic mice (longest diameter: a) $0.5 \mathrm{~mm}$, b) $0.4 \mathrm{~mm}$, c) $0.4 \mathrm{~mm}$ ) a) Medium contained $20 \mathrm{mM}$ D-mannitol from $36-72 \mathrm{~min}$. b) Medium contained $20 \mathrm{mM}$ urea from 36-72 min. c) Medium contained $20 \mathrm{mM}$ succinate from $36-72 \mathrm{~min}$

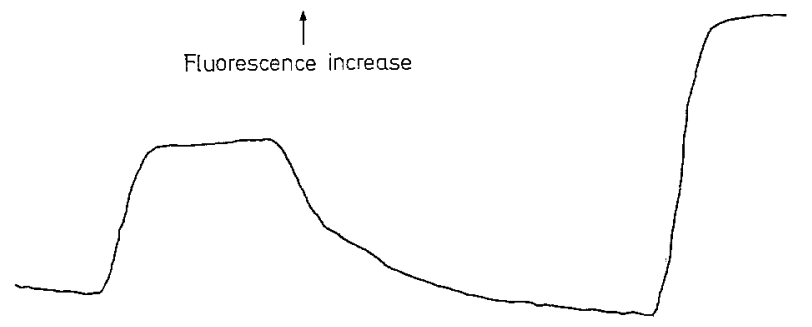

\begin{tabular}{|c|c|c|c|c|}
\hline $\begin{array}{c}\text { without } \\
\text { sub- } \\
\text { strate }\end{array}$ & $20 \mathrm{~mm}$ Mannose & without substrate & $20 \mathrm{mM}$ Fructose & $20 \mathrm{mM}$ Glucose \\
\hline & 30 & 50 & 70 & \\
\hline
\end{tabular}

Fig. 4. Effects of D-mannose $(20 \mathrm{mM})$, D-fructose $(20 \mathrm{mM})$ and $\mathrm{D}$-glucose $(20 \mathrm{mM})$ on $\mathrm{NAD}(\mathrm{P}) \mathrm{H}$-fluorescence trace of a perifused single islet $(0.45 \mathrm{~mm}$ longest diameter $)$, which was microdissected from an obese-hyperglycernic mouse

The fluorescence levels of the plateaus before addition and after removal of mannoheptulose did not differ. These kinetics are likely to be caused by the slow penetration of mannoheptulose across plasmamembranes of $\beta$-cells. Rather low levels of the substance suffice to inhibit glucose oxidation of islets [16]. The fluorescence decrease induced by glucosamine started $30-60$ sec after arrival of glucosamine at the islets and was rapidly reversible (Fig. 5). The small decrease of the fluorescence trace caused by 2-deoxyglucose was reproducible.

The unchanged fluorescence traces in the presence

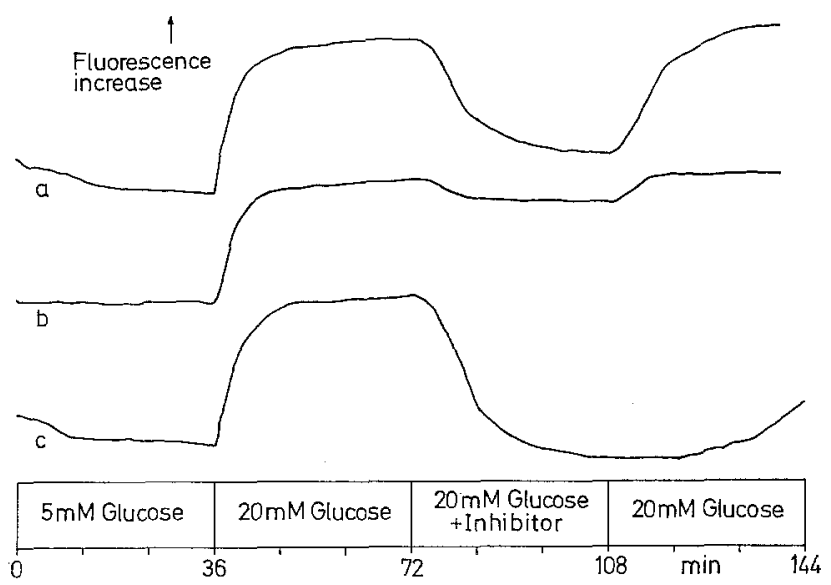

Fig. 5. NAD $(\mathbf{P}) \mathrm{H}$-fluorescence traces of perifused single islets which were microdissected from obese-hyperglycemic mice (longest diameter: a) $0.5 \mathrm{~mm}$, b) $0.4 \mathrm{~mm}$, c) $0.5 \mathrm{~mm}$ ). a) Medium contained $30 \mathrm{mM} \mathrm{D}$-glucosamine from 72-108 min. b) Medium contained $30 \mathrm{mM}$ 2-deoxyD-glucose from 72-108 min. c) Medium contained $20 \mathrm{mM}$ D-mannoheptulose from $72-108 \mathrm{~min}$

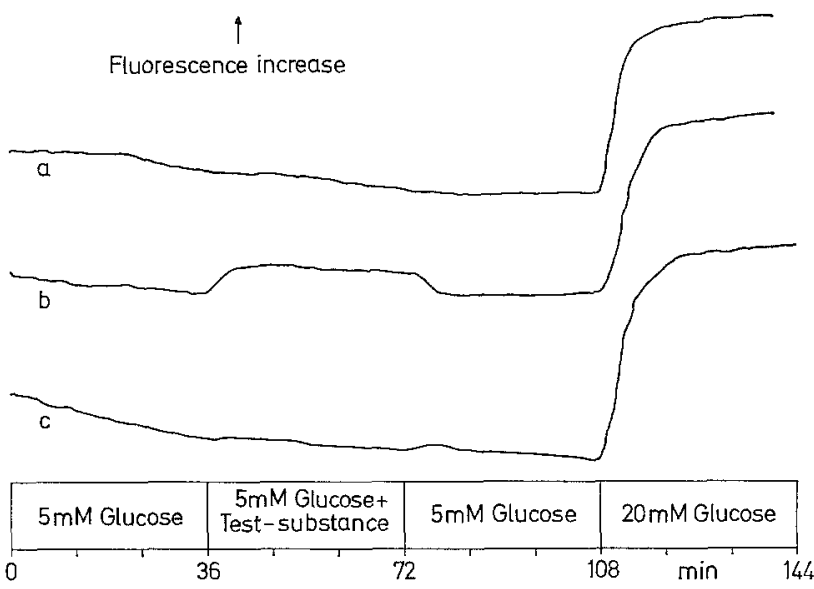

Fig. 6. NAD(P)H-fluorescence traces of perifused single islets, which were microdissected from obese-hyperglycemic mice (longest diameter : a) $0.4 \mathrm{~mm}$, b) $0.4 \mathrm{~mm}$, c) $0.45 \mathrm{~mm}$ ). a) Medium contained $10 \mu \mathrm{g} / \mathrm{ml}$ glucagon from $36-72 \mathrm{~min}$. b) Medium contained $20 \mathrm{mM}$ pyruvate from $36-72 \mathrm{~min}$. c) Medium contained $1 \mathrm{mM}$ tolbutamide from $36-72 \mathrm{~min}$

of tolbutamide or glucagon (Fig. 6) demonstrate that fluorescence increase is no obligatory consequence of stimulated insulin release. This view was supported by the unchanged glucose induced fluorescence increase when calcium was omitted from the media (Fig. 7). Addition of calcium triggered insulin release accom- 
panied by a slight, transitory fluorescence increase, which was always seen.

In contrast to mouse islets, the metabolite and cofactor patterns from rat islets remained fairly con-

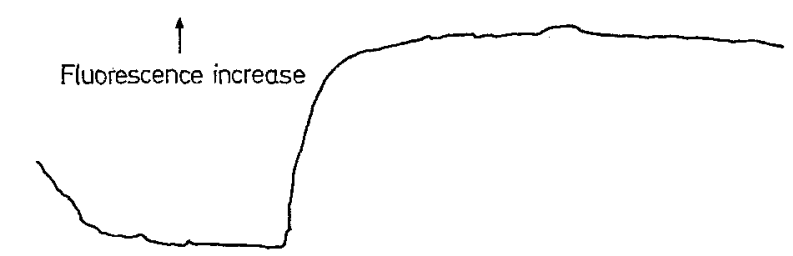

Insulin

$\mu U / \mathrm{min} /$ islet

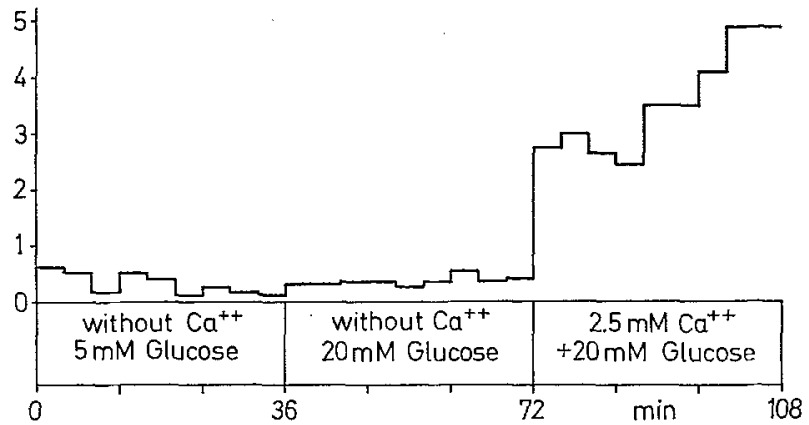

Fig. 7. Effect of calcium on NAD(P)H-fluorescence trace of a perifused single pancreatic islet (longest diameter $0.4 \mathrm{~mm}$ ), which was microdissected from an obese-hyperglycemic mouse. In a parallel experiment the amount of insulin released was immunoassayed (obese-hyperglycemic mouse, longest diameter of islet $0.4 \mathrm{~mm}$ )
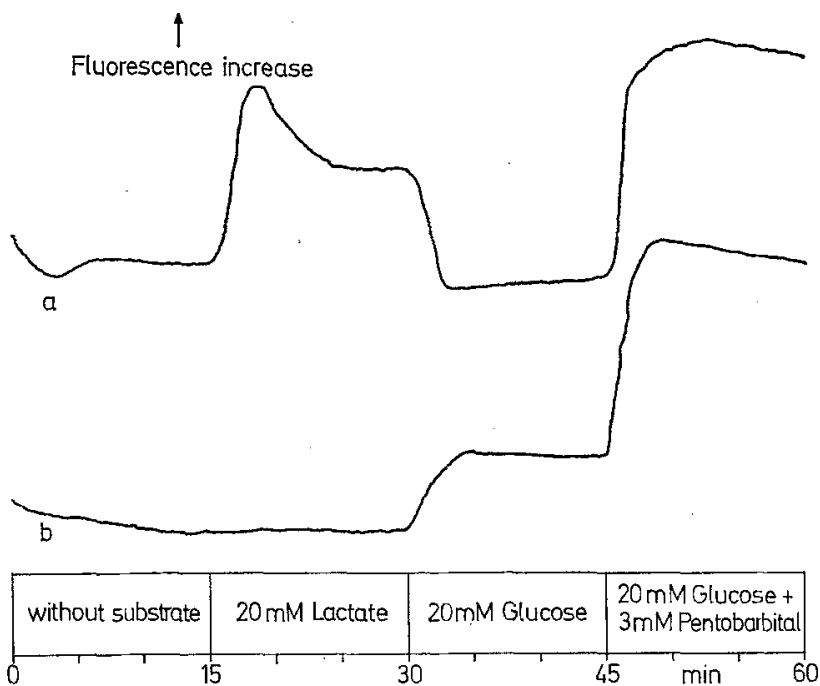

Fig. 8. Effect of L-lactate, D-glucose and pentobarbital on $\mathrm{NAD}(\mathrm{P}) \mathrm{H}$-fluorescence traces from perifused rat pancreas tissues. a) Exocrine pancreas. b) Pancreatic islet (longest diarneter $0.3 \mathrm{~mm}$ )

stant upon addition of glucose [3]. A fluorescence increase in response to $20 \mathrm{mM}$ glucose, however, took place in rat islets (Fig. 8). This fluorescence increase began $10-20$ sec after arrival of glucose at the islets.
A similar rapid increase of $\mathrm{NAD}(\mathrm{P}) \mathrm{H}$-fluorescence of rat islets was seen when switching from 3.5 to $20 \mathrm{mM}$ glucose (not shown).

$20 \mathrm{mM}$ L-lactate caused a large increase of the $\mathrm{NAD}(\mathrm{P}) \mathrm{H}-f$ fluorescence of exocrine pancreas from rats (Fig. 8) or albino mice (not shown). Islets from rats or albino mice, however, did not respond to the addition of $20 \mathrm{mM}$ L-lactate with a detectable increase of $\mathrm{NAD}(\mathrm{P}) \mathrm{H}$-fluorescence. In islets from obese hyperglycemic mice only a small fluorescence increase (about $10 \%$ of the increase induced by subsequent addition of $20 \mathrm{mM}$ glucose) could be detected when switching from a substrate-free medium to a medium containing $20 \mathrm{mM}$ L-lactate (not shown). $20 \mathrm{mM}$ pyruvate caused a small $\mathrm{NAD}(\mathrm{P}) \mathrm{H}$-fluorescence increase in islets (Fig. 6) but a decrease in exocrine pancreas from the same animals (not shown). The fluorescence trace from obesehyperglycemic mouse islets perifused without substrate was not changed by $20 \mathrm{mM}$ pyruvate (not shown).

\section{Discussion}

The question about the origin of the glucose induced fluorescence increase first raises the problem of specificity of the observed effects. In addition to $\mathrm{NAD}(\mathrm{P}) \mathrm{H}$ other tissue components are excited by this technique and emit a fluorescent light. Thus, connective tissue fluoresces, probably via collagen [5]. The background fluorescence of islets perifused without substrate is about $60 \%$ of the fluorescence observed in the pentobarbital-inhibited state. So far however, no substance other than $\mathrm{NAD}(\mathrm{P}) \mathrm{H}$ can be identified, the fluorescence (366 mu excitation, $>400 \mathrm{~m} \mu$ emission) of which changed in dependence to the redox state of the tissue [17]. All mammalian tissues analyzed with this method responded to $\mathrm{NAD}(\mathrm{P})$-reduction by anoxia or barbiturates with a fluorescence increase $[5,6,17,18,19]$. The corresponding response of pancreatic islets to pentobarbital shows that the redox state of pyridine nucleotides within this tissue can be recorded by this method.

Since mannitol or urea were without effect, shrinking or swelling of islet cells did not change the fluorescence trace. Mannitol was restricted to the extracellular water space of islets whereas urea was rapidly distributed throughout the total islet water $[20,21]$. Thus the latter substances should cause volume changes of islet cells. Finally, the glucose induced fluorescence increase did not reflect anoxia of the islet core by enhanced oxygen consumption of the outer cell layers, because succinate did not change the fluorescence trace. $17 \mathrm{mM}$ succinate increased oxygen consumption. of islets even to a greater extent than did $17 \mathrm{mM}$ glucose [22].

In the perifusion chamber the islets were floated against thin, black filaments (25 $\mu$ diameter), their shortest centre line $(0.2-\dot{0} .4 \mathrm{~mm}$ length $)$ paralleling the longitudinal axis of the chamber. Since the islets were slightly flattened by the medium flow, in most 
experiments the depth of the tissue was probably about $0.3 \mathrm{~mm}$. In kidney [17], liver [23] and brain [24] about $50 \%$ of the fluorescence signal is derived from the top $0.2-0.4 \mathrm{~mm}$. Therefore it is likely that all cell layers of pancreatic islets contributed appreciably to the NAD(P)H-fluorescence signal and that the thin outer layer of $\alpha$-cells in mouse islets [25] did not influence the results. Thus the glucose induced fluorescence increase from islets of obese-hyperglycemic mice was probably representative of $\beta$-cells. But the contribution of $\beta$-cells to the total fluorescence of islets may be less predominant when testing other stimulators of insulin release, e.g. amino acids, or when rat islets are used.

This response to glucose was not secondary to stimulated insulin release or enhanced insulin synthesis since the fluorescence increase remained unchanged in the absence of calcium (Fig. 7) or in the presence of 1 $\mathrm{mM}$ cycloheximide (Panten and Christians, unpublished observations). Moreover, the following stimulators of insulin secretion had no effect on the NAD(P) H-fluorescence trace of pancreatic islets perifused with $5 \mathrm{mM}$ glucose: $1 \mathrm{mM}$ tolbutamide (Fig. 6), $10 \mu \mathrm{g} / \mathrm{ml}$ glucagon (Fig. 6), $5 \mathrm{mM}$ citrate, $10 \mathrm{mM}$ theophylline or $10 \mathrm{mM} \mathrm{L}$-arginine (Panten and Christians, unpublished observations).

Mannoheptulose had no significant effect on glucose uptake of pancreatic islets [26] but lowered the glucose induced fluorescence increase (Fig. 5). These results support the view that phosphorylation of glucose mediated the fluorescence response. Since contribution of the pentose cycle to glucose oxidation of mouse islets is small and fails to rise with increasing glucose concentrations whereas glycolysis is enhanced severalfold [27], the glucose induced reduction of pyridine nucleotides was probably mediated by the phosphoglyceraldehyde dehydrogenase reaction. From the presented results it cannot be decided to what extent the flux of the latter reaction was changed by greater substrate availability or by diminished product inhibition due to lowered phosphate potential. The small effect of pyruvate on the NAD $(\mathbf{P}) \mathrm{H}$-fluorescence trace supports a glycolytic origin of the response to glucose. This interpretation does not mean that the fluorescence increase represents exclusively cytosol NADH. The $\beta$-cells may be well equipped with mechanisms for rapid transfer of reducing equivalents to NADP and to the mitochondrial space. Perhaps the lack of fluorescence response to lactate reflects such mechanisms and a great capacity for oxidation of cytosol NADH and not solely the lactate-dehydrogenase activity of islet cells. In islets the latter enzyme activity was 3 times lower than in exocrine pancreas [28].

The pattern of fluorimetric responses to glucose, mannose, fructose, 2-deoxyglucose, glucosamine and mannoheptulose fits well with the effects of these sugars on the oxidation rates of labelled glucose, mannose or fructose $[27,29]$ and thus indicates rapid metabolism of glucose and mannose within pancreatic islets. A rapid onset is a pre-requisite for effects of carbohydrate metabolism upon the early phase of insulin release.

Acknowledgements. The skilful assistance of Mrs. K. Illmer, Miss M. Dirks and Miss D. Beck is gratefully acknowledged. This investigation was supported by the Deutsche Forschungsgemeinschaft.

\section{References}

1. Curry, D.L., Bennett, L.L., Grodsky, G.M.: Dynamics of insulin secretion by the perfused rat pancreas. Endocrinology 83, 572-584 (1968)

2. Renold, A.E.: The beta cell and its responses: Summarizing remarks and some contributions from Geneva. Diabetes 21 (Suppl. 2), 619-631 (1972)

3. Matschinsky, F.M., Landgraf, R., Ellerman, J., Kotler-Brajtburg, J.: Glucoreceptor mechanisms in islets of Langerhans. Diabetes 21, (Suppl. 2), 555569 (1972)

4. Burr, J.M., Balant, L., Stauffacher, W., Renold, A. E.: Perifusion of rat panereatic tissue in vitro: Substrate modification of theophylline-induced biphasic insulin release. J. clin. Invest. 49, $2097-2105(1970)$

5. Chance, B., Williamson, J.R., Jamieson, D., Schöner, B.: Properties and kinetics of reduced pyridine nucleotide fluorescence of the isolated and in vivo rat heart. Biochem. Z. 341, 357-377 (1965)

6. Scholz, R., Schwarz, F.: Barbiturate und energieliefernder Stoffwechsel in der hämoglobinfrei durchströmten Leber der Ratte. Z. clin. Chem. 4, 179-189 (1966)

7. Van Rossum, G.D.V.: Observations on the fluorescence emitted by slices of rat liver and avian salt gland. Biochim. biophys. Acta (Amst.) 88, 507-516 (1964)

8. Brauser, B., Bücher, Th., Dolivo, M.: Redox transitions of cytochromes and pyridine nucleotides upon stimulation of an isolated rat ganglion. FEBS Letters $8,297-300(1970)$

9. Panten, U., Poser, W., Hasselblatt, A.: Fluorescence of reduced pyridine nucleotides of superfused panereatic islets. Proceedings of the 6 th meeting of the European Assiociation for the Study of Diabetes. Diabetologia 6, 643 (1970)

10. Hellerström, C.: A method for the microdissection of intact pancreatic islets of mammals. Acta endocr. 45, 122-132 (1964)

11. Panten, U., dal Ri, H., Poser, W., Hasselblatt, A.: Eine Methode der Gewebsumströmung für Fluoreszenzmessungen. Pflügers Arch. ges. Physiol. 323, $86-90(1971)$

12. Zaharko, D.S., Beck, L.V.: Studies of a simplified plasma insulin immunoassay using cellulose powder. Diabetes 17, 444-457 (1968)

13. Scholz, R., Thurman, R.G., Williamson, J.R., Chance, B., Bücher, Th.: Flavin and pyridine nucleotide oxidation-reduction changes in perfused rat liver. I. Anoxia and subcellular localization of fluorescent flavoproteins. J. biol. Chem. 244, 2317-2324 (1969)

14. Grodsky, G.M., Batts A.A., Bennett, L.L., Vcella, C., McWilliams, N.B., Smith, D.F.: Effects of carbohydrates on secretion of insulin from isolated rat pancreas. Amer, J. Physiol. 205, 638-644 (1963)

15. Coore, H.G., Randle, P.J.: Regulation of insulin secretion studied with pieces of rabbit pancreas incubated in vitro. Biochem. J. 93, 66-78 (1964)

16. Hellman, B., Idahl, L.-A., Lernmark, A., Sehlin, J., Simon, E., Täljedal, I.-B.: The pancreatic $\beta$-cell recognition of insulin secretagogues. I. Transport of mannoheptulose and the dynamics of insulin release. Molec. Pharmacol. 8, 1-7 (1972) 
17. Chance, B., Cohen, P., Jöbsis, F., Schoener, B.: Intracellular oxidation-reduction states in vivo. Science 137, 499-508 (1962)

18. Ogata, E., Nishiki, K., Kobayashi, S., Tateisi, K., Suzuki, H.: In vivo induced oxidation by thyrotropin of reduced pyridine nucleotides in rabbit and rat thyroid. Endocrinology 87, 552-559 (1970)

19. Kohen, E.: Pyridine nucleotide compartmentalization in glass-grown ascites cells. Exp. Cell Res. 35, 303$316(1964)$

20. Hellman, B., Sehlin, J., Täljedal, I.-B.: Transport of $\alpha$-aminoisobutyric acid in mammalian pancreatic $\beta$-cells. Diabetologia 7, 256-265 (1971)

21. Hellman, B., Sehlin, J., Täljedal, I.-B.: Calcium uptake by pancreatic $\beta$-cells as measured with the aid of ${ }^{45} \mathrm{Ca}$ and mannitol- ${ }^{3} \mathrm{H}$. Amer. J. Physiol. 221, 1795-1801 (1971)

22. Hellerström, C., Westman, S., Marsden, N., Turner, D.: Oxygen consumption of the $\beta$-cells in relation to insulin release. In: The Structure and Metabolism of the Pancreatic Islets. S. Falkmer, B. Hellman, I.-B. Täljedal (eds.) p. 315. Oxford: Pergamon Press 1970

23. Bücher, Th., Brauser, B., Conze, A., Klein, F., Langguth, O., Sies, H.: State of oxidation-reduction and state of binding in the cytosolic NADH-system as disclosed by equilibration with extracellular lactate/ pyruvate in hemoglobin-free perfused rat liver. Europ. J. Biochem. 27, 301-317 (1972)

24. Jöbsis, F.F., O'Connor, M., Vitale, A., Vreman, H.: Intracellular redox changes in functioning cerebral cortex. I. Metabolic effects of epileptiform activity. J. Neurophysiol. 34, 735-749 (1971)

25. Hellerström, C., Hellman, B., Petersson, B., Alm, G.: The two types of pancreatic A-cells and their relation to the glucagon secretion. In: The Structure and Metabolism of the Pancratic Islets S.E. Brolin, B. Hellman, H. Knutson (eds.) p. 117. Oxford: Pergamon Press 1964

26. Hellman, B., Sehlin, J., Täljedal, I.-B.: Evidence for mediated transport of glucose in mammalian pancreatic $\beta$-cells. Biochim. biophys. Acta (Amst.) 241, $147-154$ (1971)

27. Ashcroft, S.J.H., Weerasinghe, L.C.C., Bassett, J.M., Randle, P.J.: The pentose cycle and insulin release in mouse pancreatic islets. Biochem. J. 126, 525-532 (1972)

28. Hellman, B., Täljedal, I.-B.: Quantitative studies on isolated pancreatic islets of mammals. Activity and heterogeneity of lactate dehydrogenase in obesehyperglycemic mice. Endocrinology 81, 125-131. (1967)

29. Asheroft, S.J.H., Hedeskov, C.J., Randle, P.J.: Glucose metabolism in mouse pancreatic islets. Biochem. J. 118, 143-154 (1970)

Dr. U. Panten Institut für Pharmakologie und

Toxikologie der Universität

D-34 Göttingen.

Geiststraße 9

Federal Republic of Germany 